\title{
Education on Religious Moderation Among Islamic Student Organization Activists
}

\author{
Sayid Sagap*, Sya'roni Sya'roni, Arfan Arfan \\ UIN Sulthan Thaha Saifuddin Jambi \\ Jambi, Indonesia \\ *seggafuinjambi@gmail.com
}

\begin{abstract}
One of religious thought transmission media among Islamic student organizations activists was cadre education and inter-forum discussions between fellow activists. The increasing demographic of young people accompanied by open political structures and narrow job opportunities making transmission of radicalism movements possible. This paper aims to examine the moderation of religious thought and activism of Islamic student organizations activists through cadre education and their discourses on nowadays religious situations in Indonesia, particularly in Jambi where this research was specifically conducted on activists of three Islamic student organizations: PMII, HMI and KAMMI. Data collecting was carried out through observation on formal and informal caderization trainings in each organization followed with interviews of four mentors of cadre training. The results of the study indicated that religious moderation and tolerance taught and discussed among activists. They differ in views and opinions, both among activists from the same organization, as well as with other activists outside the organization, in looking at Indonesia's current socio-religious situation. However, they put significant attention on peace and sustainability of the unitary state of Indonesia or Negara Kesatuan Republik Indonesia.
\end{abstract}

Keywords: religious moderation education, Islamic student activists

\section{INTRODUCTION}

The education on religious moderation in the rising of large number of young people in Indonesia is important to be elaborated. The increase of youth demography has two sides, gives hope for the future of Indonesia as well as anxiety [1]. In 2020-2030 the total population aged 15-64 years is estimated to increase to $70 \%$ of the total population of Indonesia [2]. The demographic bonus is hopeful because historically youth have made radical contributions in social change in Indonesia, since the Youth Pledge of 1928 [3], Proclamation of 1945, Three People Demands-TRITURA of 1966, until the fall of Suharto in 1998 and the beginning of the reform era [4]. However, anxiety also arises because of the possibility of low capacity of the workforce quantity, while the era of information technology is highly disruptive and eliminates work that was once based on human labor. Religious education will be a temporary remedy for the transition of this industrial revolution era because it will encourage people not to be despair, continue to spread peace and compassion and seek glory in the world for investment in life afterwards; even in the otherside religion should be an opportunity for the spread of a more conservative identity to radicalism among young people [5], when education, reference lessons and religious teachers put the changes that exist as enemies that must be resisted. Especially if the spread of religious understanding considers the era of disruption and bonus demographics of young people in the workforce as a result of religious conspiracies to subdue or eliminate certain religions. Religious moderation and tolerance education are important to be maintained in Indonesia.

This research is part of a comprehensive study on the understanding and disputes among Activists of Islamic Student Organizations at Jambi State Universities on Indonesian Actual Religious Issues'. This research focuses on religious education in Islamic student organizations, both through formal cadre education and regular discussions within and between student activist organizations. The data were gathered via interviews in order to get a more detailed picture related to the topic of religious moderation education in each organization that is the subject of this study.

\section{METHODS}

The study uses qualitative methods by collecting data through indepth interviews, observation and data documentation. Observations were made in February 2018 of the process of free discussion of activists as well as their cadre training. While interviews were conducted with 4 mentors in cadre education who chosed because used to provide coaching as well as speakers at PMII and HMI leadership training in Jambi. Secondary data were obtained from documents and previous studies relating to the theme of this study.

\section{RADICALISM AND RELIGION MOVEMENT}

The word radical has changed to a worse meaning. Radicals that were originally rooted, a neutral word, and have historically been positive, such as the radical actions of Sumpah Pemuda in 1928 and the history of the radical contributions of youth in Indonesian social change, the word radical now increasingly leads to negative labeling due to the ongoing campaign of war against (religion) radicalism [6]. Indonesian religious studies have also made radical or radicalism issues side by side with Islam $[7,8]$. This linkage is very unfortunate, but it is immediately important to note that the linkage between radicalism and Islam is the result of an 
empirical study of the independent actions of several Islamic organizations that are attached to unilateral operations such as sweeping on maksiat practice, paramilitary training [9] and preparing to wage war in the name of Islamic solidarity with non-Muslim, even though Indonesian compatriots [10]

Institutional religious movements that experienced a period of easy growth after the Reformation Era began, such as the Islamic Defenders Front (FPI), Indonesia Hizb ut-Tahrir (HTI), Laskar Jihad, and Jemaah Ansharut Tauhid (JAT) have participated in spreading their religious ideas and thought. The openness of religious activism has quickly expanded every organization throughout Indonesia. Even the jihadis-oriented movement is proliferating, having been divided several times, until there is a direct affiliation with ISIS in the era of open democracy in Indonesia [11].

The Tarbiyah Movement which is one of the new religious movements in Indonesia inspired by the Egyptian Brotherhood movement or Ikhwanul Muslimin, continues to expand its ideas and influence not only among the general public [12], but also among university students and even students in secondary and high school. This movement developed and placed influence in tertiary institutions through the Campus Propagation Institute or Lembaga Dakwah Kampus (LDK), and also filled extra-curricular religious education spaces in public schools through Islamic spiritual activities or RoHis $[13,14]$. Representation of the Tarbiyah Movement on campus other than (or after its establishment) the Campus Propagation Institute is the Indonesian Muslim Student Action Unit (KAMMI). This organization was born on March 29, 1998, right at the end of the three-day meeting of the 11th Campus Da'wah Gathering Forum at the Muhammadiyah University of Malang Mosque [14]. Extra-curricular Islamic Spirituality in schools has existed since the 1980s. Rohis extracurricular activities are the entry point for Tarbiyah education among students. Courtesy, neatness in dress and daily life of young activists Tarbiyah makes them young accepted by teachers and principals. Those who become mentors of Islamic Spirituality (Rohis) in schools can come from the alumni of the school itself who have experienced post-school Tarbiyah education; it can also be delegates of organizations affiliated with the Tarbiyah movement and make requests to schools to fill inactive Islamic Spirituality activities; or the school itself, both Islamic Religious Education Teachers and School Principals, who ask Tarbiyah activists or organizations affiliated with the Tarbiyah Movement to be extra-curricular companions of Islamic Spirituality in their schools.

The Salafi Movement, which is sometimes in line with the Tarbiyah Movement, has also taken advantage of the opportunities of the open era of democracy after the collapse of the New Order to expand influence and involve Indonesian youth in their religious activities. Although it had begun to take part in Indonesia since the mid of 1980s, and could also be considered to originate from the Indonesian Islamic Da'wah Council which was born in the 1960s, and became the successor to the Indonesian Muslim Shura Council (Masyumi) which was banned by the Sukarno government, the Salafis became an exclusive community typical with jalabiya, imama and niqab clothing in the middle of the majority who look different. This movement evolved quickly after Indonesia's political structure opened in the late 1990s. Ja'far Umar Thalib became the first leader of the reform era of this movement by organizing the Ahlussunnah Waljamaah Communication Forum (FKAWJ) in February 1999 and spreading calls for jihad in Maluku to defend Muslims and fight Christians [15]. The appeal has been welcomed by 7000 volunteer jihadists, including young Muslims. The success of the Salafi movement in involving young people was due to the orientation of one of its proponents in Indonesia, Abu Nida, who made university students an important target for expanding Wahhabism. Abu Nida's efforts received support from his friends who had just returned from studying in Saudi Arabia [16]. The Salafi propaganda effort continues to grow today, including in Jambi, where this study was conducted.

Some of the new religious movements and religious organizations above have expanded their understanding and followers because of the open structure after the reformation, even the movement can widen its reach by creating educational institutions and mass organizations specifically for students. To the extent that this era of openness is benefited by an open process as well, every religious movement will not become a center of radicalism, because if symptoms arise that contradict public habits and feelings, these religious phenomena will be criticized to public rejection. But religious movements will become a problem if there is an underground cadre formation, quietly indoctrinating, and even encouraging cadres to act intolerant to extremists with religious arguments. The inclusion of radicalism or religious-based extremism is a 'stowaway' in the era of openness in the Indonesian era of democratic reform, both through underground movements, and can also utilize Islamic organizations that have been established to recruit followers and spread their religious understanding, including student organizations. Moderation education among students becomes important to fortify young activists of Islamic student organizations from religious-based radicalism movements.

\section{EDUCATION OF RELIGIOUS MODERATION}

The informants of this study, who were educators in the organizational cadres in the Indonesian Islamic Student Movement or PMII, Islamic Student Association or HMI as well as the Indonesian Muslim Student Action Unit or KAMMI, said that religious moderation education had been taught for a long time in each organization. Even though they did not share the actual religious issues in Indonesia such as the freezing of HTI, burning flags with monotheistic sentences, status of Habib Riziq Shihab, until the Republic of Indonesia Sharia, the cadre of mentors agreed to continuously teach tolerance to the cadres of each organization as citizen Indonesian country. They acknowledged conveying the message and understanding tolerance in diversity at formal training and non-formal discussions in their organizations is mandatory to maintain the peace and unity of the Republic of Indonesia.

The teaching to be inclusive and sensitive to diversity, in PMII organizations, has become the first output of mentoring 
or mentoring PMII new members after the New Member Acceptance Period or MAPABA. Cadre formal education in the PMII organization itself consists of four levels: 1) The Period of Acceptance of New Members abbreviated as MAPABA and participants who pass are called Mu'taqid Cadres; 2) Basic Cadre Education or PKD and participants who pass are called Mujahid Cadres; 3) Continuing Cadre Education is abbreviated as PKL and participants who pass are called Mujtahid Cadres; 4) National Cadre Education abbreviated as PKN organized by PMII Grand Management. Participants who pass are called Muharrik Cadres or movers. Formal cadre education is considered to form the character of Muslims who have the views of Ahlussunah Wal Jamaah who are tolerant, inclusive and aware of diversity as sunnatullah or natural law. Deliberation The leadership of this organization at the end of February 2019 also recommended "De-radicalizing and early detection of the spread of extreme religious understanding through schools and campuses, both formally and institutionally spread" [17].

Besides this formal cadre education, PMII also knows nonformal cadre education and mentoring as mentioned above. Non-formal cadre education is carried out since before the New Member Acceptance Period (MAPABA) until after the National Cadre Education or PKN. Examples of non-formal cadre education include Writing Education, Paralegal Education, Budget Schools, Da'wah Schools, Cyber Schools, Research Schools, Social Analysis Schools and others. The schools referred to in non-formal cadre programs are in the form of short courses and training to provide discourse and skills for PMII cadres.

PMII mentor who became a research informant, Muhammad Sobri (Interview 7/8/2019) stated that a PMII cadre would look differently and respond to religious diversity, compared to members of other extra-campus organizations. PMII cadres will be more open in associating with non-Muslims as fellow Indonesian citizens. PMII cadres can discuss minor issues to theological inter faiths issues while relaxing discussions. Labeling like liberal is often addressed to PMII members who are close friends with non-Muslims. In fact, according to Sobri, muslim should be rahmatan lil alamin or grace for whole nature. According to Sobri, in term of clothing, PMII cadre also low profile and avoid the use of religious symbols. PMII members more openly compared to members of other organizations who according to him are too well-dressed and even accentuate Muslim symbols through their cloths.

At the HMI organization, Muhammad Syahran Jailani (Interview 14/08/2019), also stated that the HMI teaches religious moderation and tolerance to its cadres, and rejects religious-based radicalism. According to this informant, the thoughts of Nurcholish Madjid, although not all of them, could represent religious beliefs adopted by HMI cadres. Nurcholis thought is like "Islam Yes Islam Party No" which wants the unity of nationalism regardless of ethnic and religious identity. However, HMI also has its own history when the XVI Congress, March 24-31, 1986 in Padang, West Sumatra. At the congress the HMI exponent was divided, some retained
Islam as the principle of the organization, and some others accepted the single principle of Pancasila which was determined by the New Order Government as the principle of all organizations. HMI activists who adhere to the principles of Islam are then called the HMI MPO and sometimes called HMI 1947 (the year Lafran Pane gave birth to HMI in Yogyakarta); while those who adhere to the Pancasila principle are called HMI DIPO. Even though the HMI of 1947 was increasingly echoing, and the HMI MPO became an organization recognized by the government, the MPO Islamic perspective still seems to be strong among HMI activists and alumni. The author's observations on a WhatsApp Group lecturer where HMI alumni and mentors were also involved, an HMI Mentor continued to give criticism towards the Government which was considered to be impartial to Muslims, as well as scholars who were considered to defend the government such as Multaqo Ulama Jambi who intended to create a cool atmosphere after the election. The HMI alumni stated that "Clerics or Ulama who make it cool may be Ulama who like to go where the wind blows". Research informants from HMI activists, Ansori (Casual Interview 07/08/2019), stated that, in his view, the political attitude of the majority of HMI activists and alumni tended to support political actors in favor of Muslims. This informant ensured that at the cadre level at HMI since the Introduction of Prospective Members or MAPERCA, then LK or Training Cadre 1 or also called Basic Training, LK 2 or Intermediate Training to LK 3-Advanced Training, the Islam taught was a peaceful Islam and became a peaceful Islam grace for the inhabitants of nature. The material of Pluralism and Rational Muslims who have taken common ground (Kalimatun Sawa) for the diversity that exists in Indonesia, the legacy of Nurcholish Madjid, is the understanding and attitude of most HMI cadres. Therefor HMI cadres can take part in various lines of life because of respect for the diversity that exists.

The Indonesian Muslim Students Student Unity Organization (KAMMI) also expressed its desire to realize its cadres as Muslim Statesmen. The regeneration in the KAMMI organization relies on an education module called Manhaj Tarbiyah 1427 Hijri which wants the output of cadres who have a Cadre Identity Index (IJDK). The orientation period of a cadre candidate is when attending a training called Pra Dauroh Marhalah (DM). The cadre education itself, besides being called Dauroh Marhalah, is also called the KAMMI Madrasah consisting of KAMMI Madrasas (MK) 1 to 3 . The core of KAMMI cadre is about developing three aspects of cadres themselves: Ruhiyah or spiritual, fikriyah (intellectuality) and Islamic or physical [18] The material provided is related to Aqeedah, Ahlak, Worship, Islamic Thaqofah, Indonesian Insights, Expertise and Professionalism, Socio-Political Ability Insights, Movement and Leadership, and Personal Development material. In the matter of the law also conveyed about the potential of Indonesia, including social diversity in Indonesia. However, differences of opinion with other student organization activists remain apparent. KAMMI activist who are prospective respondents of this study, tend to reject the term radicalism. Radicalism still seems to be considered a product in the battle of the mind 
[3] K. Foulcher, "Sumpah Pemuda: the making and meaning of a symbol of Indonesian nationhood," Asian Studies Review, vol. 24, no. 3, pp. 377410, Sep. 2000. https://onlinelibrary.wiley.com/doi/abs/10.1111/14678403.00083

(ghozwul fikri) which corners Muslims. Regardless, the desire to shape the character of Muslim Statesmen or 'Muslim Negarawan' is an evidence that KAMMI also wishes its cadres to be accepted by many parties including non-Muslim and non-Tarbiyah citizens in the Republic of Indonesia today, where anti-terrorism-based acts of religion are also the subject of government campaigns through the Agency National Counter Terrorism (BNPT); and conversely, actions and remarks in public or on social media that appear to be defending the struggle of such these faith-based terrorists, will easily be accused of being part of the same group.

\section{CONCLUSIONS}

Religious Moderation Education is a concern for three organizations that are the subject of this research. Religious Moderation is seen as part of the character of the Academic and Muslim Statesmen. Three conclusions can be made at the end of this paper: first, the three Islamic student organizations, through their mentors or activists, claim that a moderate perspective is an important part of regeneration in their cadre organizations. Second, despite claiming to be moderate, PMII activists appear to be more progressive in relations and perspectives on relations between religious communities, including refuse NKRI Bersyariah issues, while KAMMI activists tend to reject the term radicalism (based on religion). Third, from the study of the cadre organization module, it appears that the aim of each organization is to contribute their best cadres to the glory of Indonesia in the future. As a religiously and ethnically diverse country, Indonesia's future will also require a diversity of national development cadres who have variant perspectives and varian solutions toward various national and Islamic ummah problems.

\section{ACKNOWLEDGMENT}

The authors thank to UIN Sulthan Thaha Saifuddin Jambi for the 2019 research grant given and made it possible to publish this paper through the $4^{\text {th }}$ Asian Education Symposium.

\section{REFERENCES}

[1] BKKBN. "Negara Harus Siap Bonus Demografi." [Online]. Available: https://www.bkkbn.go.id/detailpost/negara-harus-siap-bonus-demografi.

[2] BAPPENAS, "Proyeksi Penduduk Indonesia 2010-2035." BAPPENAS, BPS, UNFPA, 2013. Avalaible: https://www.bappenas.go.id/files/5413/9148/4109/Proyeksi_Penduduk_I ndonesia_2010-2035.pdf
[4] D. Lee, "Images of Youth: on the Iconography of History and Protest in Indonesia," History and Anthropology, vol. 22, no. 3, pp. 307-336, Sep. 2011.

https://www.tandfonline.com/doi/abs/10.1080/02757206.2011.595003

[5] M. N. Azca, "Yang Muda Yang Radikal: Refleksi Sosiologis terhadap Radikalisme Kaum Muda Muslim di Indonesia Passca Orde Baru", presented at the Dies Natali Ke-57 Fakultas Ilmu Sosial Ilmu Politik UGM, Yogyakarta, 05-Dec-2012.

[6] Fitzgerald, "Being labeled a 'radical' is meant to be an insult. History tells us otherwise," The Guardian, USA, 20-Jan-2014. Avalaible: https://www.theguardian.com/commentisfree/2014/jan/20/we-needradicals-for-social-change

[7] M. van Bruinessen, "Genealogies of Islamic radicalism in post-Suharto Indonesia," South East Asia Research, vol. 10, no. 2, pp. 117-154, Jul. 2002.

[8] S. Bamuallim, Ed., Kaum Muda Muslim Milenial: Konservatisme, Hibridasi Identitas, dan Tantangan Radikalisme. Yogyakarta: CSRC, 2018 .

[9] N. Hasan, "Laskar Jihad Islam, Militancy And The Quest For Identity In Post-New Order Indonesia," Disertasi, Utrecht University, Netherland, 2005.

[10] S. Umam, "Radicalism Muslims in Indonesia: The Case of Ja'far Umar Thalib and The Laskar Jihad," Exploration in Southeast Asian Studies, vol. 6 , no. 1, pp. 1-26, Spring 2006.

[11] Abdullah, "Radikalisasi Gerakan Jamaah Ansharut Tauhid Dan Pengaruh Isis Di Indonesia,” Jurnal Sosiologi Reflektif, vol. 12, no. 2, pp. 213-232, 2018.

[12] Salman, "The Tarbiyah Movement: Why People Join This Indonesian Contemporary Islamic Movement," Studi Islamika, vol. 13, no. Number 2, pp. 171-240, 2006.

[13] Pusat Pengkajian Islam dan Masayrakat, "Guru Agama, Toleransi dan Isu-Isu Kehidupan Keagamaan Kontemporer di Indonesia," Laporan Hasil Penelitian, 2016.

[14] M. Sidiq, KAMMI Dan Pergulatan Reformasi, Kiprah Politik Aktivis Dakwah Kampus dalam Perjuangan Demokratisasi di Tengah Gelombang Krisis Nasional Multidimensi. Solo: Era Intermedia, 2003.

[15] N. Hassan, "The Salafi Movement in Indonesia: Transnational Dynamics and Local Development," Comparative Studies of South Asia, Africa and the Middle East, vol. 27, no. 1, pp. 83-94, 2007.

[16] N. Hassan, "The Drama of Jihad: The Emergence of Salafi Youth in Indonesia," in Being Young and Muslim: New Cultural Politics in the Global South and North., Oxford: Oxford University Press, 2010, pp. 49-62.

[17] Keputusan-Keputusan MUSPIMNAS 2019, "Khidmat untuk Negeri, PMII dalam Narasi Pembangunan Bangsa." 2019.

[18] Sudarsono, IJTIHAD MEMBANGUN BASIS GERAKAN. Jakarta: Muda Cendekia, 2010. 